\title{
Foetal Chondrodysplasia: Intrauterine Diagnosis
}

\author{
${ }^{1}$ A. G. Adesiyun, ${ }^{2}$ A. Eka and ${ }^{3}$ M. O. A. Samaila \\ Departments of ${ }^{1}$ Obstetrics and Gyanecology, ${ }^{2}$ Radiology and ${ }^{3}$ Pathology, Ahmadu Bello University Teaching \\ Hospital, Shika-Zaria, Kaduna State, Nigeria \\ Reprint requests to: Dr. Adebiyi G. Adesiyun, P. O. Box 204, Kaduna, Kaduna State, Nigeria \\ E-mail:adebiyi_g@yahoo.com
}

\begin{abstract}
Chondrodysplasias are rare occurrence. We present a case of short-limbed chondrodyplasia diagnosed in a 22 week fetus of a 28 year old. She was para $4^{+0}$ with two children alive. She had similar occurrences in her last two pregnancies. The index pregnancy and the last two eventful pregnancies were preceded with ingestion of trado-herbal drug to treat subfertility.
\end{abstract}

Keywords: Chondrodysplasias, Intrauterine diagnosis, ultrasound

\begin{abstract}
Résumé
Des chondrodysplasies arrivent très rarement. Il s'agit d'une étude d'un cas de la chondrodyplasie membres courts diagnostique chez un foetus âgé de 22 semaines d'une femme âgée de 28 ans. Elle était para $4+0$ avec deux enfants vivants. Elle avait eu des expériences semblabes pendant sa dernière deux grossesses. L'index de la grossesse et les deux dernières grossesses étaient précédées par l'ingestion de la drougue trado-herbal afin de soigner la sous fertilité.
\end{abstract}

Mots-clés: Chondrodysplasie, diagnostique intracuterin, ultra-son

\section{Introduction}

Chondrodysplasias refer to a group of disorders that affect skeletal development and growth. There are more than a hundred distinct entities of which achondroplasia is the commonest. ${ }^{1}$ They result from gene mutation of 'chondrodysplasia genes' that are essential for skeletal and growth development. ${ }^{1}$ This is a report of short-limbed foetal chondrodysplasia diagnosed at booking for antenatal care. .

\section{Case report}

She was a 28 year old para $4^{+0}$ housewife. The last two deliveries were stillborn at twenty eight and thirty weeks respectively. Both stillborns were noticed to have short upper and lower limbs. There was no family history of similar disorder. She took tradoherbal drugs daily for months to treat subfertility before the index pregnancy and the last two pregnancies that ended in stillbirths.

She registered for antenatal care at twenty weeks of gestation. Biochemical and hematological test did not reveal abnormal data. Obstetric sonography however showed a live foetus at twenty two weeks with marked shortening of both humerus and femur (Figures 1 and 2), there was also polyhydramnios. The sonographic humeral length was $11 \mathrm{~cm}$ and femoral length was $14 \mathrm{~cm}$, against the $5^{\text {th }}$ percentile reference value of $28 \mathrm{~cm}$ and $29 \mathrm{~cm}$ for the humerus and femur respectively at 22 weeks gestation. She was counseled, but desired to continue with the pregnancy.

She presented at 30 weeks gestation with intrauterine foetal death. Labour was induced and a female stillbirth (weight $1.2 \mathrm{~kg}$ ) delivered, with features of chondrodysplasia (Figure 3). The couple was appropriately counseled before discharge from the hospital.

Figure 1: Ultrasound, showing rudimentary femur (arrow)

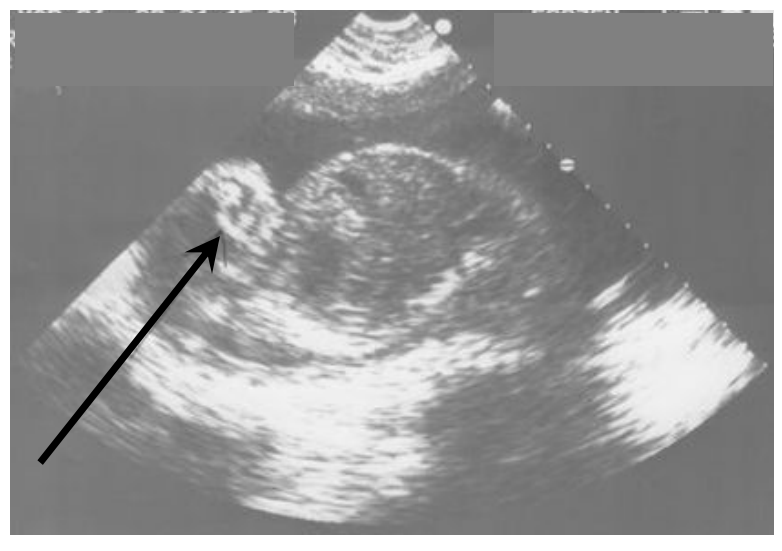


Figure 2: Ultrasound showing rudimentary humerus (arrow)

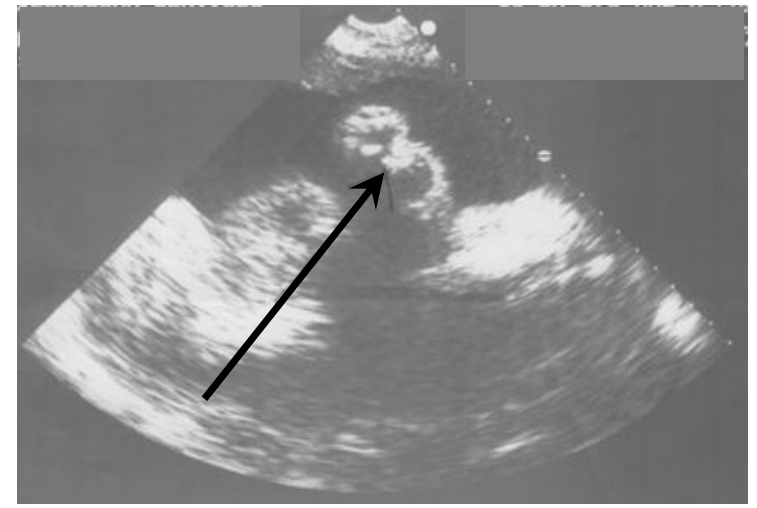

Figure 3: The foetus, with short limbs

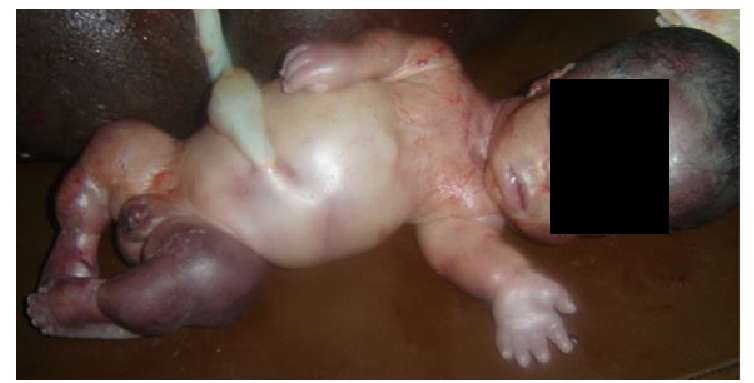

\section{Discussion}

Chondrodysplasias manifest with either predominant short-limbed or short trunk abnormalities. ${ }^{1}$ Though the manifestation is usually dominated by skeletal abnormalities, involvements of non-skeletal tissues such as congenital heart defect, cataract, retinal detachment, intestinal atresia, renal cyst and genital hypoplasia are not uncommon. ${ }^{1}$ The disorder may be lethal or non-lethal. The lethal type results in intrauterine foetal death or still-birth; this may be the type our patient had in view of the three successive intrauterine deaths of short-limbed fetuses.

The disproportionate skeletal manifestation of this disorder distinguishes chondrodyplasia from other causes of short stature such as mucopolysaccharidoses, mucolipidoses and some form of osteogenesis imperfect. ${ }^{2}$ Antenatal diagnosis, which our patient benefited from, is based on ultrasonographic discrepancy between the gestational age and the length of the long bones. Diagnostic accuracy can be enhanced by using 3-D ultrasonography alone or with intrauterine 3-D helical computerized tomography. ${ }^{3,4}$ In a high risk pregnancy, molecular genetic testing of foetal DNA obtained by aminocentesis or chorionic villus sampling at 15-18 weeks and 8-11 weeks gestation respectively may be done. ${ }^{5,6}$

In non-lethal forms of chondrodysplasia, radiology will reveal the segment of the long bone with greatest shortening which maybe rhizomelic, mesomelic or acromelic for proximal, middle and distal segment shortening respectively.

Management of the affected baby should be tailored to the specific disorder. This includes genetic testing/counseling, prevention/correction of skeletal deformities and treatment of non-skeletal complications. ${ }^{1}$ Growth hormone therapy in pharmacologic doses and surgical limb lengthening procedure have been proposed. ${ }^{7,8}$

In this case report, although of borderline significance is the linkage of trado-herbal drug ingestion to the pathogenesis of chondrodysplasia because the fact is not well established. However, with increasing patronage of alternative (unorthodox) medical practice in some lesser developed countries, conscious effort should be directed towards finding the mutagenic and teratogenic profile of herbal drugs before they are registered for public use.

\section{References}

1. Horton WA, Hecht JT. The skeletal dylasias. In: Behrman RE, Kliegman RM, Jenson HB (eds). Nelson textbook of pediatrics. Saunders, Philadelphia, 2000; 2113-2132

2. Smith R. Disorders of the skeleton. In: Weatherall DJ, Ledingham JGG, Warrell DA. (eds). Oxford textbook of medicine. David Stanford, Oxford, 1984: 17.3-17.36

3. Krakow D, Williams J $3^{\text {rd }}$, Poehl M, Rimoin DL, Platt LD. Use of three-dimensional ultrasound imaging in the diagnosis of prenatal-onset skeletal dysplasias. Ultrasound Obstet Gynecol 2003; 21: 467-742

4. Ruano R, Molho M, Roume J, Ville Y. Prenatal diagnosis of fetal skeletal dysplasias by combining two-dimensional and threedimensional ultrasound and intrauterine threedimensional helical computer tomography. Ultrasound Obstet Gynecol 2004; 24: 134-146

5. Bellus GA, Escallon CS, Ortiz de luna R, et al. First-trimester prenatal diagnosis in couple at risk or homozygous achondroplasia. Lancet 1994; 334: 1511-1512

6. Shiang R, Thompson LM, Zhu YZ, et al. Mutation in the transmembrane domain of FGFR3 cause the most common genetic form of dwarfism, achondroplasia. Cell 1994; 78: 335342

7. Shohat M, Tick D, Barakat S, BU X, Melmed S, Rimon DL. Short-term recombinant human growth hormone treatment increases growth of anchondroplasia. J Clin Endocrinol Metab 1996; 81: 4033- 4037

8. Peretti G, Memeo A, Paronzini A, Marzorati S. Stagged lengthening in the prevention of dwarfism in achondroplasia children: a preliminary report. J Pediatr Orthop B 1995; 4: $58-64$ 